\title{
Comparative Anatomical Studies on the Nerves and Muscles of the Posterior Limb of the Northern Fur Seal and Cat
}

By

\section{Tadayuki Nakanishi, Masao Yamamoto and Yoshimaru Suenaga}

The First Department of Anatomy, Asahikawa Medical College, 3-11, Kaguraoka, Kaguracho, Asahikawa, 078-11.

-Received for Publication, September 2, 1977-

\section{Introduction}

Recently, we had the opportunity to dissect four northern fur seal fetuses and to compare the findings with those of cats. We found a strong similarity in the arrangement of the lumbosacral plexuses of both species, although the attachment of some muscles of the posterior limb of the fur seal, which is specialized to form a paddle-like device for aquatic locomotion, is remarkably different from that in the cat.

In view of this adaptation to different life environments, it is interesting to consider the detail relationships between the nerves and muscles of the posterior limbs of both species. The purpose of this study is thus to describe these structures precisely, giving particular attention to the nerves of the posterior limb of the fur seal, and to discuss the various findings including analogies of musculature between the two species in order that the manner in which the attachment of muscles is related to the nerve branching patterns may be elucidated.

Table 1. Description of the fetuses of northern fur seals, kittens observed in this study

\begin{tabular}{c|c|c|c|c|c|c}
\hline & \multicolumn{2}{|c|}{ Fetuses of northern fur seals } & \multicolumn{2}{c}{ Kittens } \\
\cline { 2 - 6 } & I & II & III & IV & I & II \\
\hline Sex & male & male & female & female & male & male \\
\hline Age (months) & near term & near term & near term & near term & $\begin{array}{c}\text { near term } \\
(2)\end{array}$ & $\begin{array}{c}\text { near term } \\
(2)\end{array}$ \\
\hline Nose-Tail length (cm) & 66 & 61 & 59 & 63 & 38 & 37 \\
\hline Body weight (g) & 3820 & 3660 & 3002 & 3210 & 550 & 540 \\
\hline
\end{tabular}




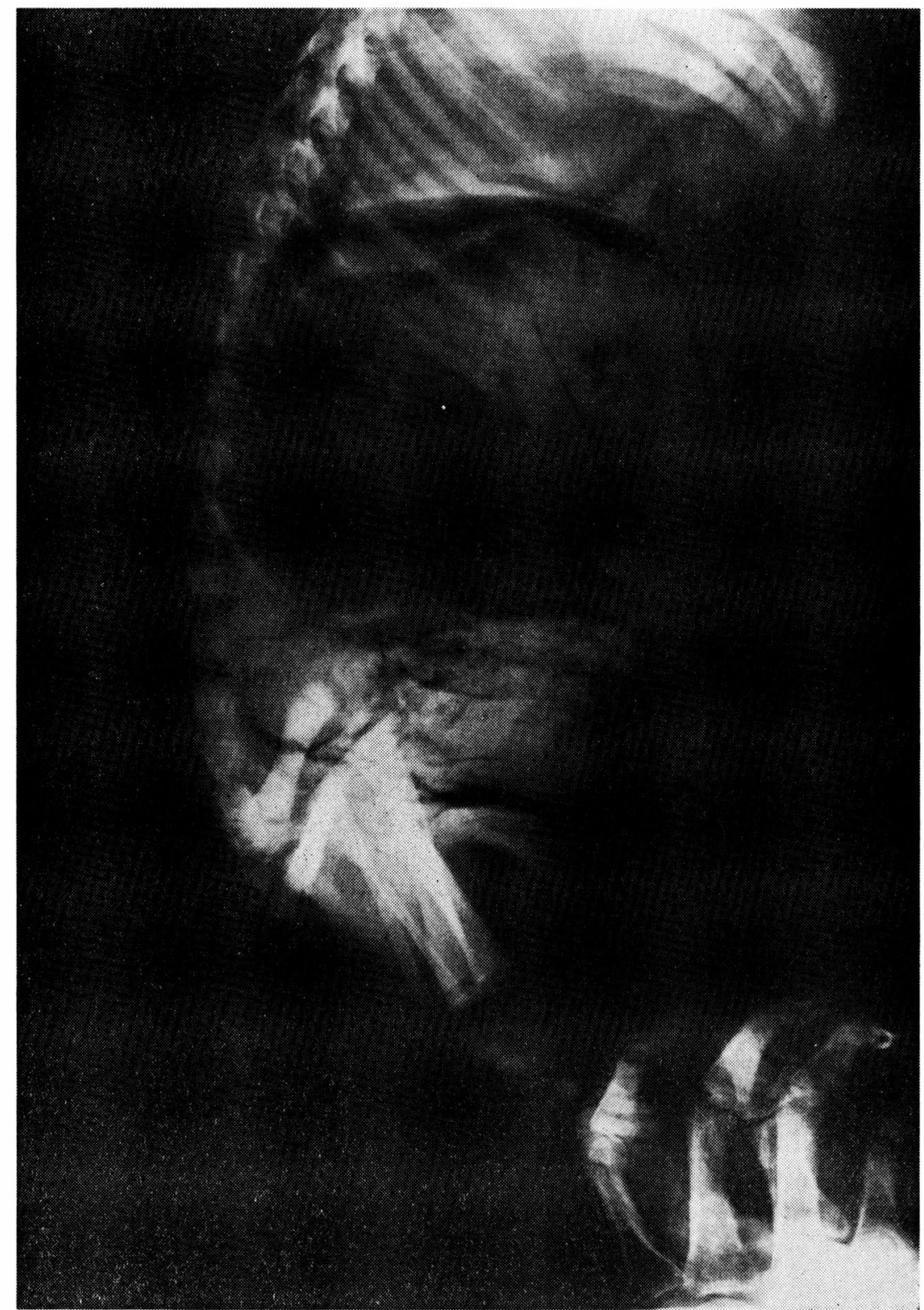

Fig. 1. Radiogram of a northern fur seal showing the femur, tibia and fibula. The shadow in the lower right-hand corner is the operator's hand.

\section{Materials and Methods}

The specimens used were four fetuses of the northern fur seal (Callorhinus ursinus), four adult cats, and two kittens. General descriptions of these specimens are given in Table 1. The northern fur 


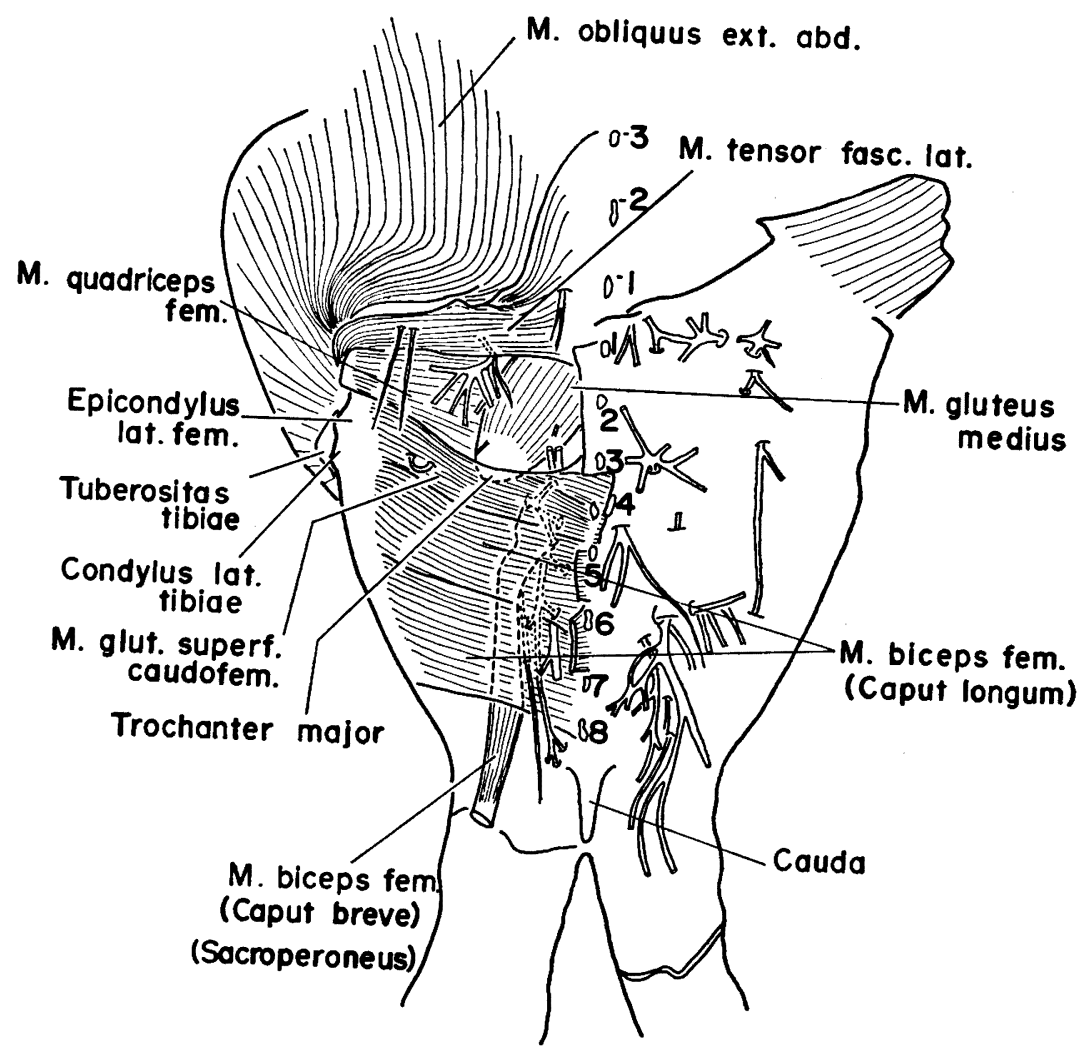

Fig. 2. Muscles and cutaneous nerves of the buttock and thigh of a male fur seal (posterior view, left side).

seal fetuses had been collected earlier by one of us (Suenaga) at the Sanriku beach, Japan, and had been preserved in 50\% alcohol. The cats and kittens were anesthetized with pentobarbital sodium (Nembutal, $25-30 \mathrm{mg} / \mathrm{kg}$, IP.), sacrified by transcardiac perfusion with $10 \%$ formalin and fixed in the same liquid for seven days.

Dissection of the specimens was performed as follows. First, the skin of the gluteal region and the back of the thigh was removed and the posterior female cutaneous nerve was traced to the level of the inferior border of the long head of the biceps femoris. The inferior gluteal nerve, muscular branches of the sciatic nerve and perineal nerves were also dissected out and tied with different colored threads for analysis and determination of the muscles and skin areas supplied by these ibranches. The gluteus superficialis was then removed and the origins of the posterior femoral cutaneous, pudendal and sciatic nerves were traced (Fig. 4).

As occasion demanded, each specimen was observed under a stereoscopic microscope. After gross observation, the nerves and their sur- 


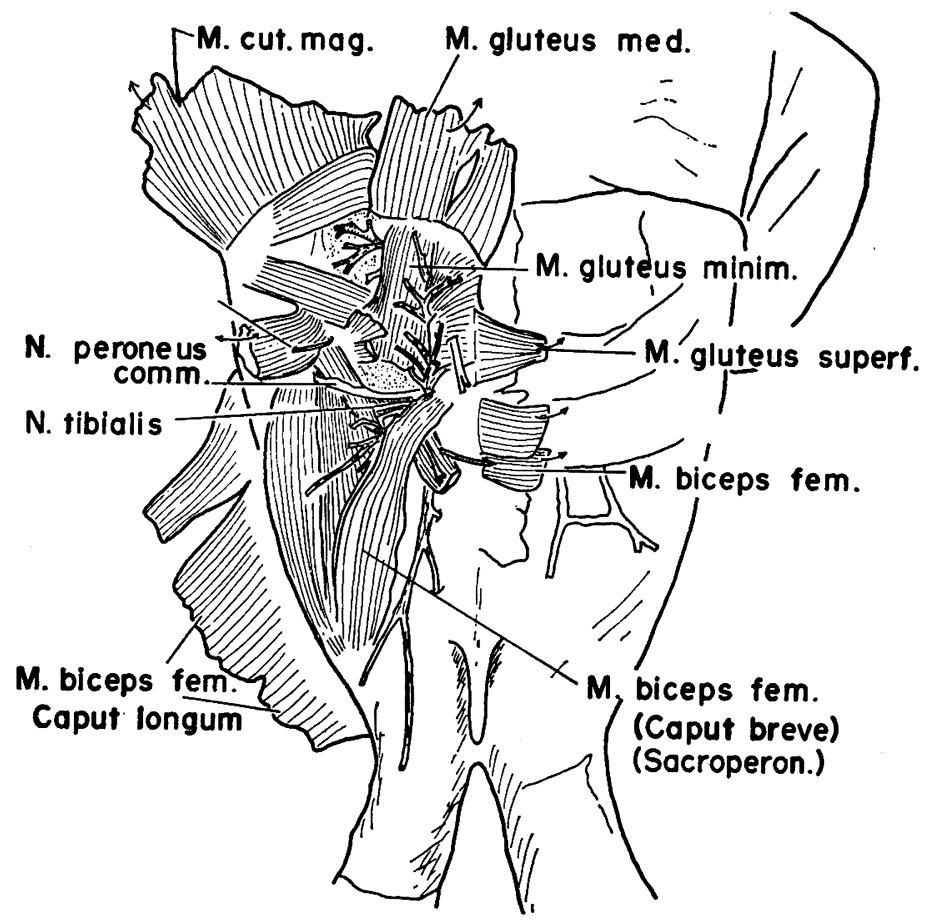

Fig. 3. Muscles of the gluteal region and back of the thigh of a male fur seal (posterior view, left side), deep to the gluteus medius and biceps femoris. Note the course of the tibial and common peroneal nerves and the sacroperoneus.

Table 2. Relative length of skeletal element in Monkeys, Kangaroos, cats and northern fur seals.

(Apex of ilium to ischial tuberosity $=5.0$ )

\begin{tabular}{l|c|c|c|c}
\hline \multicolumn{1}{c|}{ Animals } & \multicolumn{2}{c|}{ Bauschulte } & \multicolumn{2}{c}{ Nakanishi \& Yamamoto } \\
\cline { 2 - 5 } Muscles & Monky & Kangaroo & $\begin{array}{c}\text { Kitten } \\
\text { (4 sides) }\end{array}$ & $\begin{array}{c}\text { Fur seal fetus } \\
\text { (3 sides })\end{array}$ \\
\hline Ilium & 3.5 & 3.0 & 3.0 & 2.5 \\
Ischium & 1.5 & 2.0 & 2.0 & 2.5 \\
Pelvic total & 5.0 & 5.0 & 5.0 & 5.0 \\
Height of Pelvis & 2.0 & 1.3 & 1.4 & 2.5 \\
Trochanter major to the hip joint & 0.5 & 0.6 & 0.7 & 0.7 \\
Hip joint to lateral condyle & 6.5 & 4.4 & 6.8 & 4.0 \\
Femur total & 7.5 & 5.0 & 7.5 & 4.7 \\
Crus & 6.5 & 9.0 & 7.0 & 6.3 \\
Calcaneus-ancle joint & 0.7 & 1.2 & 1.2 & 1.1 \\
Ancle joint-Metatarsophalangeal joint & 3.2 & 3.7 & 4.3 & 5.3 \\
Toe & 2.1 & 1.6 & 1.5 & 4.4 \\
Foot total & 6.0 & 6.5 & 7.0 & 10.8 \\
Total length of posterior limb & 19.5 & 20.5 & 21.5 & 21.8 \\
\hline
\end{tabular}




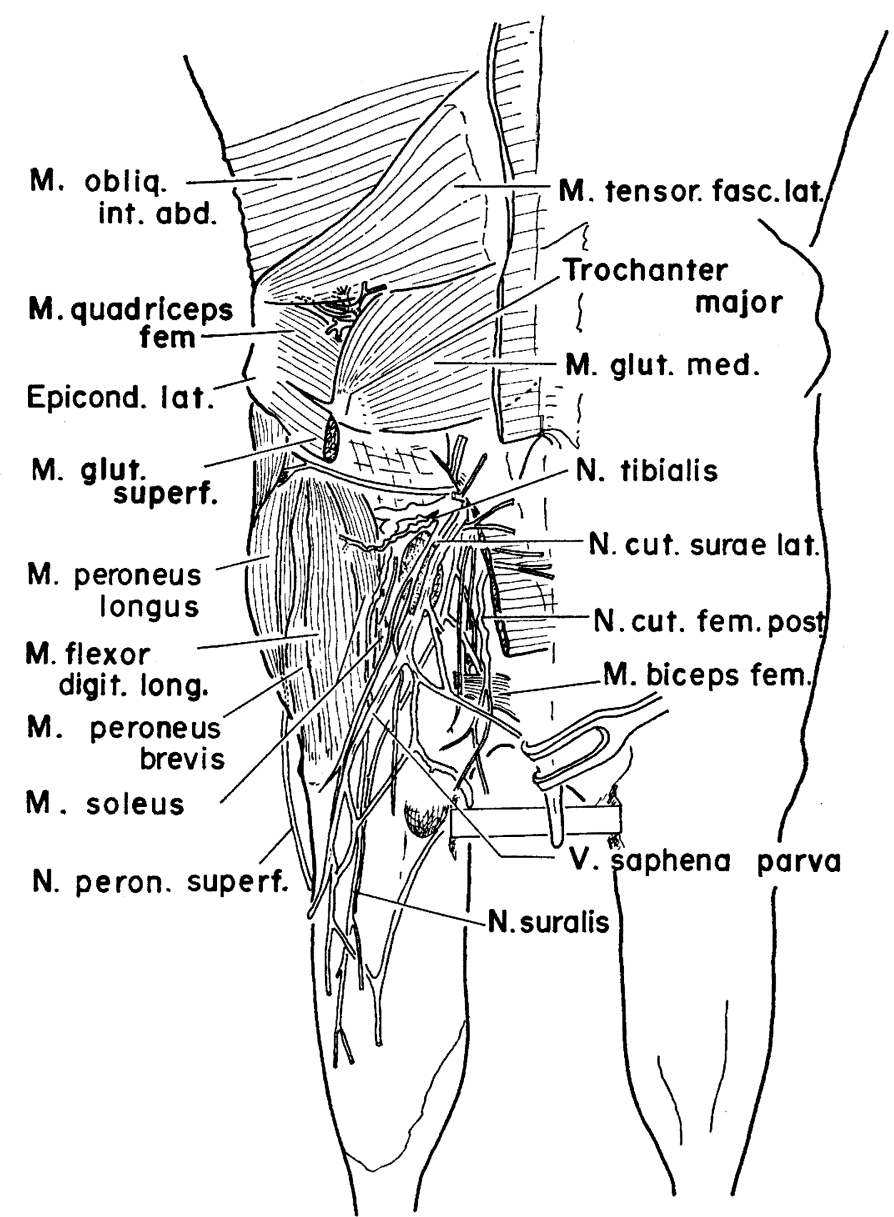

Fig. 4. Nerves and vessels of the back of the thigh of a male fur seal (posterior view, left side). The sacroperoneus has been removed.

rounding structures were recorded in the form of drawings. The muscles of the posterior limb of the fur seal and kitten were then both removed individually, dried for three days in an oven to constant weight at $100^{\circ} \mathrm{C}$, and weight on an electric microbalance to the nearest $0.0001 \mathrm{~g}$. However, a few which proved extremely difficult to separate anatomically, were removed and weighed together. All of the muscles were separated from their tendons at the level of the last vestige of muscle tissue following Bryden's methods. ${ }^{3)}$

The identification and nomenclature of the nerves and muscles examined were based on Nakanishi's report. ${ }^{14)}$ In order to maintain a uniform and consistent terminology for the structures in these specimens, Nomina Anatomica (1965) was adopted as far as possible. However, when the terms applied to fur seals and cats were not found in this Nomina, 
the terminology recommended by the Nomina Anatomica Veterinaria (1967) was used.

\section{Observations}

I. Bones and muscles

The vertebral column of the fur seal contains seven cervical, fifteen thoracic, five lumbar, three sacral and fourteen caudal vertebrae, and that of the cat contains seven, thirteen, seven, three and twenty-two vertebrae, respectively. Despite these differences, the total number of presacral vertebrae is the same in both species. As a results, the spinal nerves except the coccygeal ones may be grouped as follows: cervical, 8 ; thoracic, 15 ; lumbar, 5 ; sacral, 3 in the fur seal ; and cervical, 8 ; thracic, 13 ; lumbar, 7 ; sacral, 3 in the cat. The abbreviations C, T, $\mathrm{L}, \mathrm{S}$ and Co followed by the appropriate Roman numeral are used here to indicate the individual vertebrae, and those followed by Arabic figures indicate the individual spinal nerves.

The relative lengths of the skeletal elements of monkeys, kangaroos, kittens and fur seals are listed in Table 2. Those of the monkey and kangaroo are cited from Bauschulte's (1972) report..) The ilium and femur are relatively small in the fur seal compared to the kitten, monkey and kangaroo. The relative length of the crus is similar in the fur seal and monkey, but greater in the kitten and kangaroo. On the other hand, the total length of the foot is considerably larger in the fur seal. The observed relative lengths may be summarized as follows:

illum, femur and crus: kitten $>$ fur seal fetus

ischium and foot: fur seal fetus $>$ kitten

The origins (O) and insertions (I) of certain muscles discussed in this study are given in Table 3. The attachments of the muscles of the posterior limb of the fur seal are almost indentical to those descrived by Howell (1928) $)^{\eta}$ and Mori $(1958)^{11)}$ in sea lions (Zalophus).

With regard to their origins and insertions, seven muscles displayed remarkable differences between the fur seal and cat. These were the tensor fasciae latae, quadratus femoris, biceps femoris, semitendinosus, semimembranosus, gastrocnemius, and tibialis posterior. The tensor fasciae latae of the cat originates from the anterior margin of the ventral border of the ilium, while in the fur seal it originates from the spinous spines of $\mathrm{L}_{\mathrm{III}}-\mathrm{S}_{\mathrm{I}}$ and thoracolumber fascia. With regard to the gastrocnemius, in the fur seal it had only a medial head. In general, the insertions of the other muscles in the fur seal have shifted more caudally than the corresponding insertions in the cat (Table 3).

The absolute and relative dry weights of muscle groups and individual muscles of the kittens and fur seals are indicated in Table 4. The psoas minor, caudofemoralis, gluteus minimus, sacroperoneous, ex- 
Table 3. Comparison of some muscles of the posterior limb in northern fur seals and cats

\begin{tabular}{|c|c|c|c|c|}
\hline \multirow{2}{*}{\multicolumn{3}{|c|}{ Muscles Animals }} & Nakanishi & Crouch \\
\hline & & & Callorhinus ursinus & Felis catus \\
\hline \multicolumn{2}{|c|}{$\begin{array}{l}\text { M. tensor } \\
\text { fasciae latae }\end{array}$} & $\begin{array}{l}\mathrm{O} \\
\mathrm{I}\end{array}$ & $\begin{array}{l}\mathrm{L}_{111}-\mathrm{S}_{1} \text { spinosus proc., fascia } \\
\text { lumbodorsalis } \\
\text { Lig. patellae }\end{array}$ & $\begin{array}{l}\text { anterior margin of ventral } \\
\text { border of ilium } \\
\text { fascia lata }\end{array}$ \\
\hline \multicolumn{2}{|c|}{$\begin{array}{l}\text { M. gluteus } \\
\text { superficialis }\end{array}$} & $\begin{array}{l}\mathrm{O} \\
\mathrm{I}\end{array}$ & $\begin{array}{l}\text { spines of } \mathrm{S}_{111}-\mathrm{Co}_{1} \\
\text { caudal of greater troch., } \\
\text { dorsal femur }\end{array}$ & $\begin{array}{l}\text { transverse proc. of } \\
\mathrm{S}_{111}-\mathrm{Co}_{1} \text {, gluteal fascia } \\
\text { caudal side of greater troch. }\end{array}$ \\
\hline \multicolumn{2}{|c|}{$\begin{array}{l}\text { M. gluteus IV } \\
\text { (M. capsularis) }\end{array}$} & $\begin{array}{l}\mathrm{O} \\
\mathrm{I}\end{array}$ & not found & $\begin{array}{l}\text { ilium } \\
\text { cranial surface of femur, } \\
\text { distal of greater troch. }\end{array}$ \\
\hline \multicolumn{2}{|c|}{$\begin{array}{l}\text { M. quadratus } \\
\text { femoris }\end{array}$} & $\begin{array}{l}\mathrm{O} \\
\mathrm{I}\end{array}$ & $\begin{array}{l}\text { craniad of ischial tuberosity } \\
\text { proximal } 1 / 4 \text { of femur }\end{array}$ & $\begin{array}{l}\text { lateral surface of ischium } \\
\text { caudal border of greater } \\
\text { trochanter }\end{array}$ \\
\hline \multirow{3}{*}{ 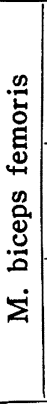 } & $\begin{array}{l}\text { M. caudo- } \\
\text { femoralis } \\
\text { (Caput } \\
\text { longum by } \\
\text { Howell) }\end{array}$ & $\begin{array}{l}\text { O } \\
\mathrm{I}\end{array}$ & $\begin{array}{l}\text { spines of } \mathrm{Co}_{1}-\mathrm{Co}_{11} \\
\text { dorsal of femur, lat. condyl } \\
\text { of tibia }\end{array}$ & $\begin{array}{l}\text { transverse proc. of } \mathrm{Co}_{11} \text { and } \\
\mathrm{Co}_{111} \\
\text { middle of lateral border of } \\
\text { patella }\end{array}$ \\
\hline & \multicolumn{2}{|c|}{\begin{tabular}{l|l} 
Caput longum & $\mathrm{C}$ \\
(Caput & \\
posterius & $\mathrm{I}$ \\
by Howell) & $\mathrm{P}$
\end{tabular}} & $\begin{array}{l}\mathrm{Co}_{11}-\mathrm{Co}_{\mathrm{VII}} \\
\text { proximal, caudolateral of fibula }\end{array}$ & $\begin{array}{l}\text { ventral surface of ischial } \\
\text { tuberosity } \\
\text { prox. } 1 / 3 \text { tibia and patella }\end{array}$ \\
\hline & $\begin{array}{l}\text { M. sacro- } \\
\text { peroneus } \\
\text { (M. tenuis- } \\
\text { simus Caput } \\
\text { breve) }\end{array}$ & $\begin{array}{l}\text { O } \\
\mathrm{I}\end{array}$ & $\begin{array}{l}\text { lateral of caudal m., spine of } \\
\mathrm{Co}_{1} \\
\text { lateral malleolus }\end{array}$ & $\begin{array}{l}\text { transverse proc. of } \mathrm{Co}_{11} \\
\text { Biceps femoris }\end{array}$ \\
\hline \multicolumn{2}{|c|}{$\begin{array}{l}\text { M. semiten- } \\
\text { dinosus }\end{array}$} & $\begin{array}{l}\mathrm{O} \\
\mathrm{I}\end{array}$ & $\begin{array}{l}\text { spines of } \mathrm{Co}_{11}-\mathrm{Cov} \text {, lateral of } \\
\text { caudal mm. } \\
\text { distal end of tibia }\end{array}$ & $\begin{array}{l}\text { ischial tuberosity } \\
\text { dorsal border of tibia }\end{array}$ \\
\hline \multicolumn{2}{|c|}{$\begin{array}{l}\text { M. semimem- } \\
\text { branosus }\end{array}$} & $\begin{array}{l}\mathrm{O} \\
\mathrm{I}\end{array}$ & $\begin{array}{l}\text { ischial tuberosity and ramus } \\
\text { anterior, proximal } 1 / 4 \text { tibia }\end{array}$ & $\begin{array}{l}\text { caudal border of tuberosity } \\
\text { and ramus of ischium } \\
\text { medial surface of femur, } \\
\text { medial epicondyle }\end{array}$ \\
\hline \multirow{3}{*}{ 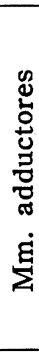 } & $\begin{array}{l}\text { M. add. long. } \\
\text { (I by Mori) } \\
\text { (1 by Howell) }\end{array}$ & $\begin{array}{l}\text { O } \\
\text { I }\end{array}$ & $\begin{array}{l}\text { cranial pubis } \\
\text { medial epicondyl of femur }\end{array}$ & $\begin{array}{l}\text { cranial border of pubis } \\
\text { linea aspera of femur }\end{array}$ \\
\hline & $\begin{array}{l}\text { M. add. brev. } \\
\text { (II by Mori) } \\
(4,5,6 \text { by } \\
\text { Howell })\end{array}$ & $\begin{array}{l}\mathrm{O} \\
\mathrm{I}\end{array}$ & $\begin{array}{l}\text { cranial pubis, caudad of } \\
\text { pectineopsoas proc. } \\
\text { lat. lesser troch., } 2 / 4 \text { femoral } \\
\text { shaft }\end{array}$ & $\begin{array}{l}\text { whole length of pelvic } \\
\text { symphysis, part of } \\
\text { ischial ramus }\end{array}$ \\
\hline & $\begin{array}{l}\text { M. add. mag. } \\
\text { (III by Mori) } \\
(2,3 \text { by } \\
\text { Howell })\end{array}$ & $\begin{array}{l}\text { O } \\
\mathrm{I}\end{array}$ & $\begin{array}{l}\text { caudad of pubis } \\
\text { medial epicondyl of femur \& } \\
\text { tibia }\end{array}$ & lateral lip of linea aspera \\
\hline \multicolumn{2}{|c|}{ M. gracilis } & $\begin{array}{l}\mathrm{O} \\
\mathrm{I}\end{array}$ & $\begin{array}{l}\text { superior ramus of pubis } \\
\text { ventral, distal } 2 / 3 \text { of tibia }\end{array}$ & $\begin{array}{l}\text { symphysis pubis } \\
\text { 3rd sixth of tibia }\end{array}$ \\
\hline \multicolumn{2}{|c|}{$\begin{array}{l}\text { M. gastro- } \\
\text { cnemius }\end{array}$} & $\begin{array}{l}\mathrm{O} \\
\mathrm{I}\end{array}$ & $\begin{array}{l}\text { medial epicondyl of femur } \\
\text { (only the medial head) } \\
\text { calcaneus }\end{array}$ & $\begin{array}{l}\text { lat. and medial condyl femur } \\
\text { calcaneus }\end{array}$ \\
\hline
\end{tabular}


Table 3. Continued

\begin{tabular}{l|c|l|l}
\hline M. soleus & O & $\begin{array}{l}\text { proximal end of fibula } \\
\text { calcaneus }\end{array}$ & $\begin{array}{l}\text { fibular head, prox. 2/5 fibula } \\
\text { calcaneus }\end{array}$ \\
\hline M. plantaris & O & $\begin{array}{l}\text { lat. epicondyl femur } \\
\text { plantar fascia borders of } \\
\text { adjoining digits }\end{array}$ & $\begin{array}{l}\text { lateral border of patella, } \\
\text { ventral border of fabella } \\
\text { tendon of Flex. digit. brevis }\end{array}$ \\
\hline $\begin{array}{c}\text { M. flexor digit. } \\
\text { longus (comm.) }\end{array}$ & I & $\begin{array}{l}\text { medial border of fibula } \\
\text { inteross. membrane } \\
\text { digitus I, II, III, IV, V }\end{array}$ & $\begin{array}{l}\text { proximal half of tibia, fibular } \\
\text { head } \\
\text { distal phalanges of digits II-V }\end{array}$ \\
\hline $\begin{array}{c}\text { M. flexor } \\
\text { hallucis longus }\end{array}$ & O & $\begin{array}{l}\text { fibular head, tibiofibular lig. } \\
\text { tendon of Flex. digit. long }\end{array}$ & $\begin{array}{c}\text { caudal surface of tibia, fibular } \\
\text { head, inteross. membr. } \\
\text { distal phalanges of digits II-V }\end{array}$ \\
\hline $\begin{array}{c}\text { M. tibialis } \\
\text { posterior }\end{array}$ & O & $\begin{array}{l}\text { post. tibial fossa, inteross. } \\
\text { membr., fibular head }\end{array}$ & $\begin{array}{c}\text { fibular head } \\
\text { lateral central bone }\end{array}$ \\
\hline $\begin{array}{c}\text { M. extensor } \\
\text { hallucis longular, ventral of medial } \\
\text { cuneiform }\end{array}$ & I & $\begin{array}{l}\text { interosseus membrane } \\
\text { lst phalanx of hallux }\end{array}$ & absent \\
\hline
\end{tabular}

Table 4. Individual muscle weights, and their percentage of total posterior limb muscle weight in northern fur seals and kittens

\begin{tabular}{l|c|c|c|c}
\hline \multicolumn{1}{c|}{ Animals } & \multicolumn{2}{c|}{ Northern fur seal } & \multicolumn{2}{c}{ Kitten } \\
\cline { 2 - 5 } Muscles & $\mathrm{Wt}(\mathrm{g})$ & $\%$ & $\mathrm{Wt}(\mathrm{g})$ & $\%$ \\
\hline Iliopsoas & 0.2621 & 3.0 & 0.1859 & 4.4 \\
Psoas minor & 0.2037 & 2.4 & 0.0504 & 1.2 \\
Gluteus superficialis & 0.2039 & 0.3 & 0.0272 & 0.7 \\
Caudofemoralis & 0.3033 & 3.8 & 0.0334 & 0.8 \\
Gluteus medius & 0.3349 & 3.9 & 0.1664 & 4.0 \\
Gluteus minimus & 0.2241 & 2.6 & 0.0435 & 1.0 \\
Tensor fasciae latae & 0.2803 & 3.2 & 0.0958 & 2.3 \\
Piriformis & 0.0431 & 0.5 & 0.0269 & 0.6 \\
Gemellus superior & 0.0195 & 0.2 & 0.0102 & 0.2 \\
Obturatorius internus & 0.0520 & 0.6 & & \\
Gemellus inferior & 0.0589 & 0.7 & 0.0738 & 1.8 \\
Quadratus femoris & 0.0925 & 1.1 & 0.0388 & 0.9 \\
Sartorius & 0.1021 & 1.2 & 0.1664 & 4.0 \\
Rectus femoris & 0.2789 & 3.2 & 0.1941 & 4.6 \\
Vastus medialis & 0.0561 & 0.7 & 0.1219 & 2.9 \\
Vastus intermedius et lateralis & 0.3565 & 4.1 & 0.3675 & 8.8 \\
Pectineus & 0.0530 & 0.6 & 0.0159 & 0.4 \\
Adductor longus & 0.0444 & 0.5 & 0.0256 & 0.6 \\
Adductor brevis & 0.4633 & 5.4 & 0.4112 & 9.8 \\
Adductor magnus & & & & \\
\hline & & & & \\
\hline
\end{tabular}


Table 4. (Continued)

\begin{tabular}{l|l|l|l|l}
\hline \multicolumn{1}{c|}{ Muscles } & \multicolumn{2}{|c|}{ Fur seal } & \multicolumn{2}{c}{ Kitten } \\
\cline { 2 - 5 } \cline { 4 - 5 } & $\mathrm{Wt}(\mathrm{g})$ & $\%$ & $\mathrm{Wt}(\mathrm{g})$ & $\%$ \\
\hline Gracilis & 0.2919 & 3.4 & 0.0962 & 2.3 \\
Obturatorius externus & 0.1718 & 2.0 & 0.0482 & 1.2 \\
Biceps femoris & & & & \\
$\quad$ Caput longum & 0.5904 & 6.9 & 0.3664 & 8.8 \\
$\quad$ (Caput breve) & 0.1587 & 1.8 & 0.0059 & 0.1 \\
Semitendinoperoneus) & 0.2637 & 3.1 & 0.1290 & 3.1 \\
Semimembranosus & 0.1926 & 2.2 & 0.4228 & 10.1 \\
Tibialis anterior & 0.3252 & 3.8 & 0.1081 & 2.6 \\
Extensor digit. longus & 0.3101 & 3.6 & 0.0692 & 1.7 \\
Extensor hallucis longus & 0.1027 & 1.2 & - & - \\
Peroneus longus & 0.1714 & 2.0 & 0.0308 & 0.7 \\
Peroneus brevis & 0.2280 & 2.6 & 0.0326 & 0.8 \\
Gastrocnemius & & & & \\
$\quad$ Caput laterale & 0.4108 & 4.8 & 0.2322 & 5.6 \\
Soleus & 0.5099 & 5.9 & 0.0830 & 2.3 \\
Plantaris & 0.3480 & 4.0 & 0.0096 & 0.2 \\
Popliteus & 0.2094 & 2.4 & 0.0404 & 1.0 \\
Tibialis posterior & 0.2170 & 2.5 & 0.0238 & 0.6 \\
Flexor digit. longus & 0.2092 & 2.4 & 0.0328 & 0.8 \\
Flexor hall. longus & 0.1414 & 1.6 & 0.0966 & 2.3 \\
Extt. hall. et digit. breves & 0.0344 & 0.4 & 0.0193 & 0.5 \\
Lumbricales & 0.0260 & 0.3 & 0.0085 & 0.2 \\
Flexx. hall. et digit. breves & 0.0240 & 0.3 & 0.0240 & 0.6 \\
Quadratus plantae & - & - & 0.0024 & 0.1 \\
Thenaris et Hypothenaris & 0.2208 & 2.6 & 0.0237 & 0.6 \\
Interossei dorss. et plantt. & 0.1769 & 2.1 & 0.0776 & 1.9 \\
\hline
\end{tabular}

tensor digitorum longus, extensor hallucis longus, peronei longus et brevis, soleus, palantaris, popliteus, tibialis posterior, and flexor digitorum longus are considerably larger in the fur seal than the kitten. In particular, the caudofemoralis, gluteus minimus, sacroperoneus, extensor hallucis longus, peronei longus et brevis, soleus, plantalis, tibialis posterior, and flexor digitorum longus each weigh approximately three times as much in the fur seal as in the kitten. On the other hand, the gluteus superficialis, sartorius, vasti medialis, intermedius et lateralis, semimembranosus, and caput laterale $\mathrm{m}$. gastrocnemii are larger in the kitten than the fur seal (by a factor exceeding 2). In particular, the relative weight of the sartorious, vastus medialis, semimembranosus, and caput laterale m. gastrocnemii in the kitten are almost three times as much as in the fur seal. 
II. The lumbosacral plexus and its branches in the northern fur seal

The lumbosacral plexus of fur seals consists of the ventral rami of the last three lumbar, three sacral and first coccygeal nerves. Since the fifth lumbar nerve is connected to the first sacral nerve by a strong branch (Fig. 9), this plexus is not divided into two components, a lumbar and a sacral plexus.

1) The lateral femoral cutaneous nerve (Figs. 5, 8 and 9)

This nerve arises from $\mathrm{L}_{3}$ and $\mathrm{L}_{4}$. It emerges from the cranial border of the tensor faciae latae and the anterior superior iliac spine, passing ventrolaterally between the former muscle and the obliquus externus abdominis to the cranioventral surface of the thigh. It then descends giving off a few small branches to the skin of the greater trochanter to the cranial part of the patella, divides into two branches

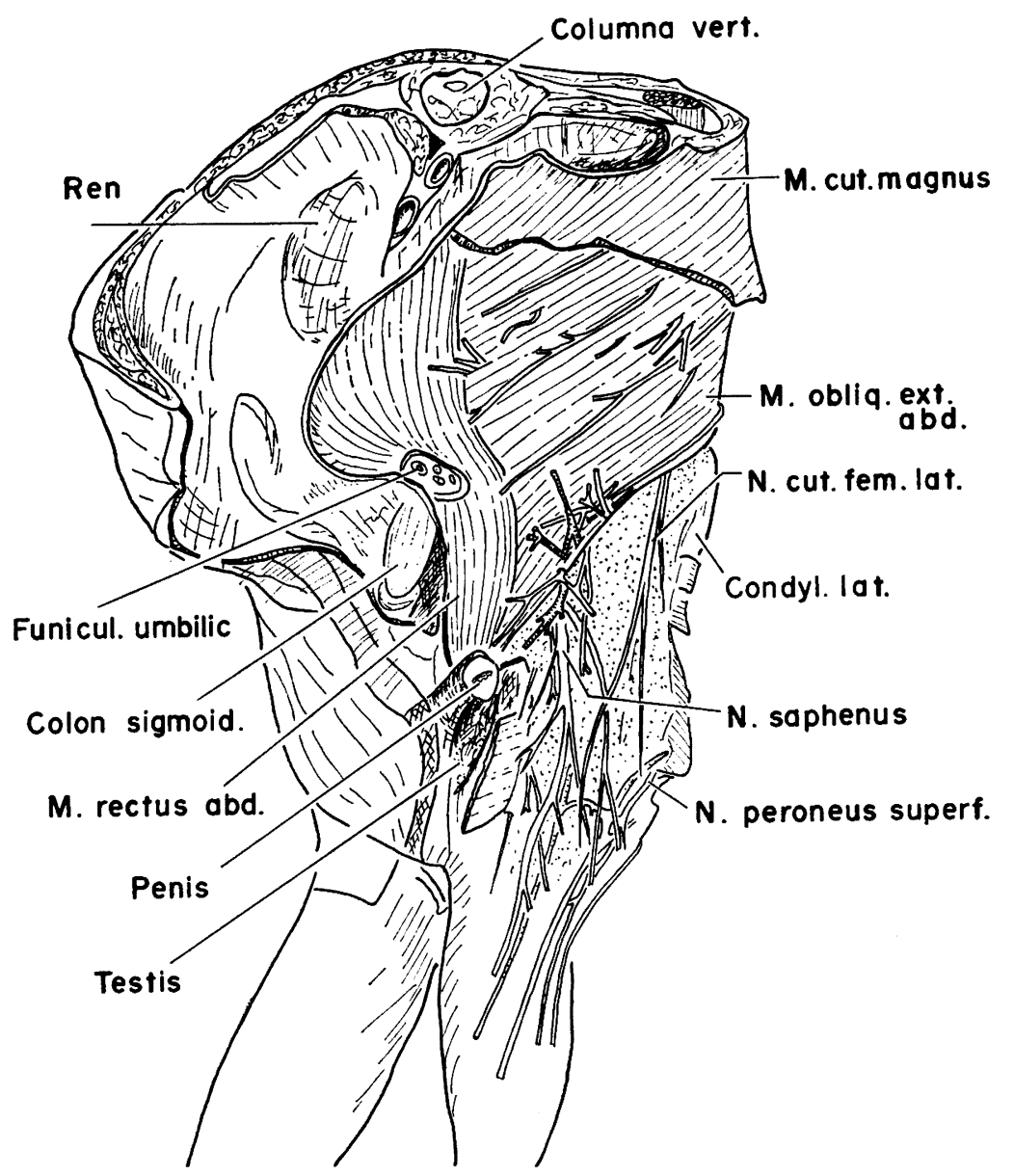

Fig. 5. Anterior abdominal wall and cutaneous nerves of the posterior limb of a male fur seal (anterior view, left side). 
to descend ventral to the insertion of the tensor fasciae latae, and ends by supplying the skin over the foot.

2) The obturator nerve (Figs. 8 and 9)

This nerve arises from $\mathrm{L}_{5}\left(\mathrm{~L}_{4}\right)$. It pierces the ventromedial part of the obturator externus and divides into anterior and posterior branches. The anterior branch descends caudally on the ventrolateral surface of the insertions of the adductor magnus and brevis, emerges from the caudal margin of the pectineus, and descends ventral to the adductor longus to enter the cranial margin of the gracilis.

3) The femoral nerve (Figs. 5, 6, 8 and 9)

This nerve arises from $\left(\mathrm{L}_{3}\right), \mathrm{L}_{4}$ and $\mathrm{L}_{5}$ in the substance of the psoas major. It passes caudolaterally between the psoas and iliacus to the ventral margin of the ilium, emerges from the medial border of the origin of the rectus femoris caudolateral to the sartorius, and immediately divides into three branches. One of these branches descends medial to the rectus femoris to become the saphenous nerve. Another branch enters the medial margin of the rectus femoris. Here it divides into two branches to supply the vasti lateralis, intermedius and medi-

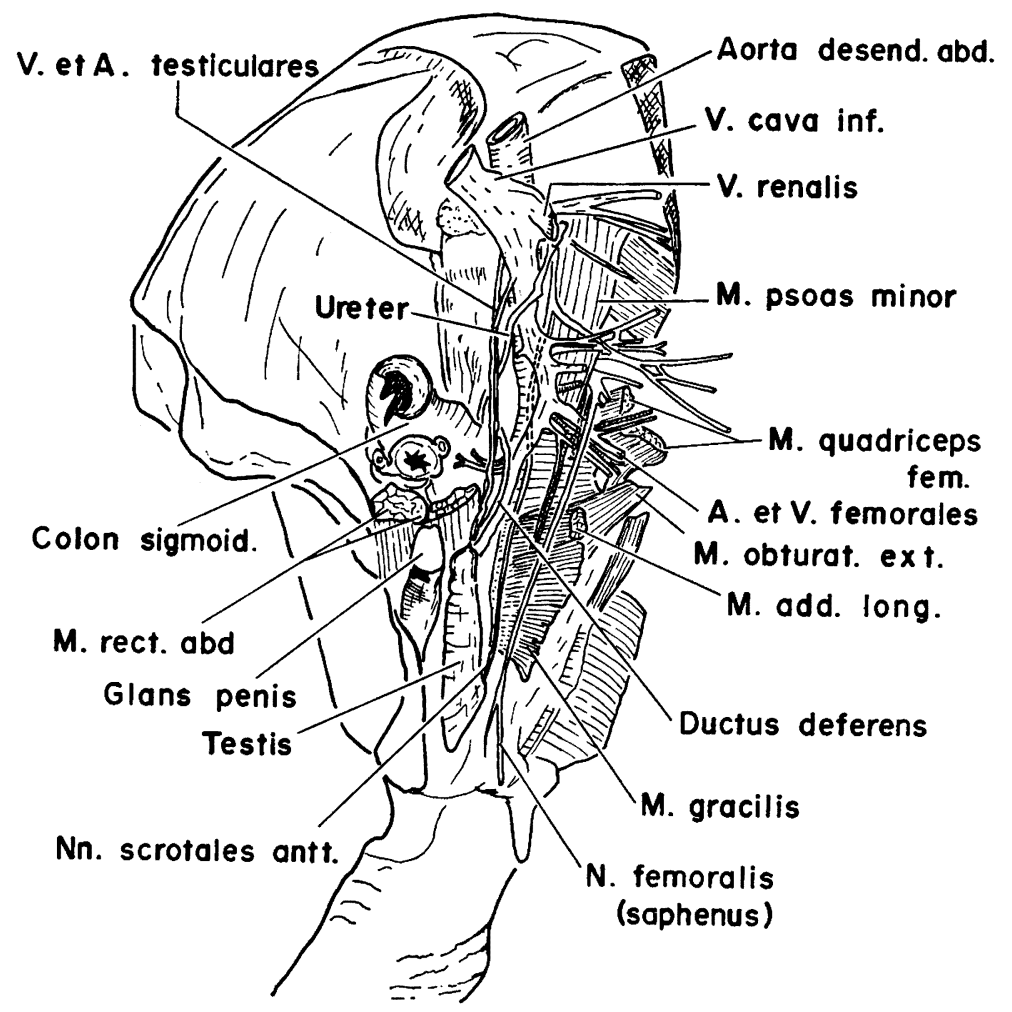

Fig. 6. Nerves, vessels and muscles of the pelvic and adductor regions of a male fur seal (anterior view, left side). 
alis. The third branch, the nerve to the sartorius, arises from the main trunk lateral to the psoas minor and runs transversely to enter this muscle.

a) The saphenous nerve (Figs. 5 and 6)

This nerve enters the thigh caudal to the inguinal ligament and mediocaudal to the tensor fasciae latae, accompanied by the femoral vessels. It descends ventrolaterally between the ventral abdominal wall and crus, and then runs on the ventral surface of the crus, divides into four or five branches at the level of the tibial insertion of the gracilis and ends by supplying the skin of the dorsum of the foot. The longest branch reaches as far as the medial side of the first toe.

4) The nerve to the quadratus femoris, obturator internus and gemelli superior et inferior (Fig. 9)

This nerve arises from $\mathrm{L}_{5}$ and $\mathrm{S}_{1}$. It runs caudally on the ventral surface of the tendon of the obturator internus giving off a few small branches to this muscle and the gemelli, and enters the ventral surface of the quadratus femoris.

5) The nerves to the piriformis. (Fig. 9)

These consist of three separate nerves which arise from a fine loop between $S_{1}$ and $S_{2}$ to enter the deep surface of the muscle.

6) The superior gluteal nerve (Figs. 8 and 9)

This nerve arises from $L_{5}$ and $S_{1}$. The upper branch pierces the gluteus minimus cranial to the piriformis giving off branches to this muscle and ends by supplying the gluteus medius. The lower branch crosses deep to the gluteus minimus to enter the tensor fasciae latae.

7) The inferior gluteal nerve (Figs. 8 and 9)

This nerve arises in common with the common peroneal nerve from the lumbosacral plexus, forming the originating common trunk with the sural nerve. It enters the gluteal region at the caudal border of the piriformis, runs on the dorsal surface of the gemelli and tendon of the obturator internus, descends lateral to the origin of the sacroperoneous (Howell), and ends by entering the gluteus superficialis and caudofemoralis.

8) The posterior femoral cutaneous nerve (Figs. 4, 8 and 9)

This nerve is formed from three roots which arise from the loop between $\mathrm{S}_{2}$ and $\mathrm{Co}_{1}$, the roots of pudendal and the tibial nerves, respectively. It passes with the muscular branches to the long head of the biceps femoris on the medial side of the sacroperoneus and pierces the long head with the sciatic vein. It then reaches the superficial fascia at the level of $\mathrm{Co}_{\mathrm{v}}$ to end by supplying the skin of the tail, around the anus and medial malleolus and heel, which lies immediately medial to the anus.

9) The common peroneal nerve (Figs. 3, 7, 8 and 9)

This nerve arises from the dorsal surface of the lumbosacral plexus. 
At its origin, it gives off the inferior gluteal nerve and then crosses laterocaudally, accompanying the latter nerve along the dorsal surface of the quadratus femoris to the caudal border of the greater trochanter, passing deep to the gluteus superficialis and caudofemoralis to reach the lateral surface of the head of the fibula. It enters the peronei dividing into a deep and a superficial peroneal nerve, where the stem lies deep to the border between the caudofemoralis and long head of the biceps femoris (flexor cruris lateralis). At the lateral surface of the neck of the fibula, the superficial peroneal nerve bends caudad at right angles to descends between the peronei longus and brevis, and then between the peroneous longus and extensor digitorum longus. It reaches the superficial fascia of the ventral surface of the latter muscle at the distal third of the crus, and its courses continue along the ventral surface of the tendon of this muscle in the dorsum of the foot to end by supplying the skin of the dorsal surface of the adjacent

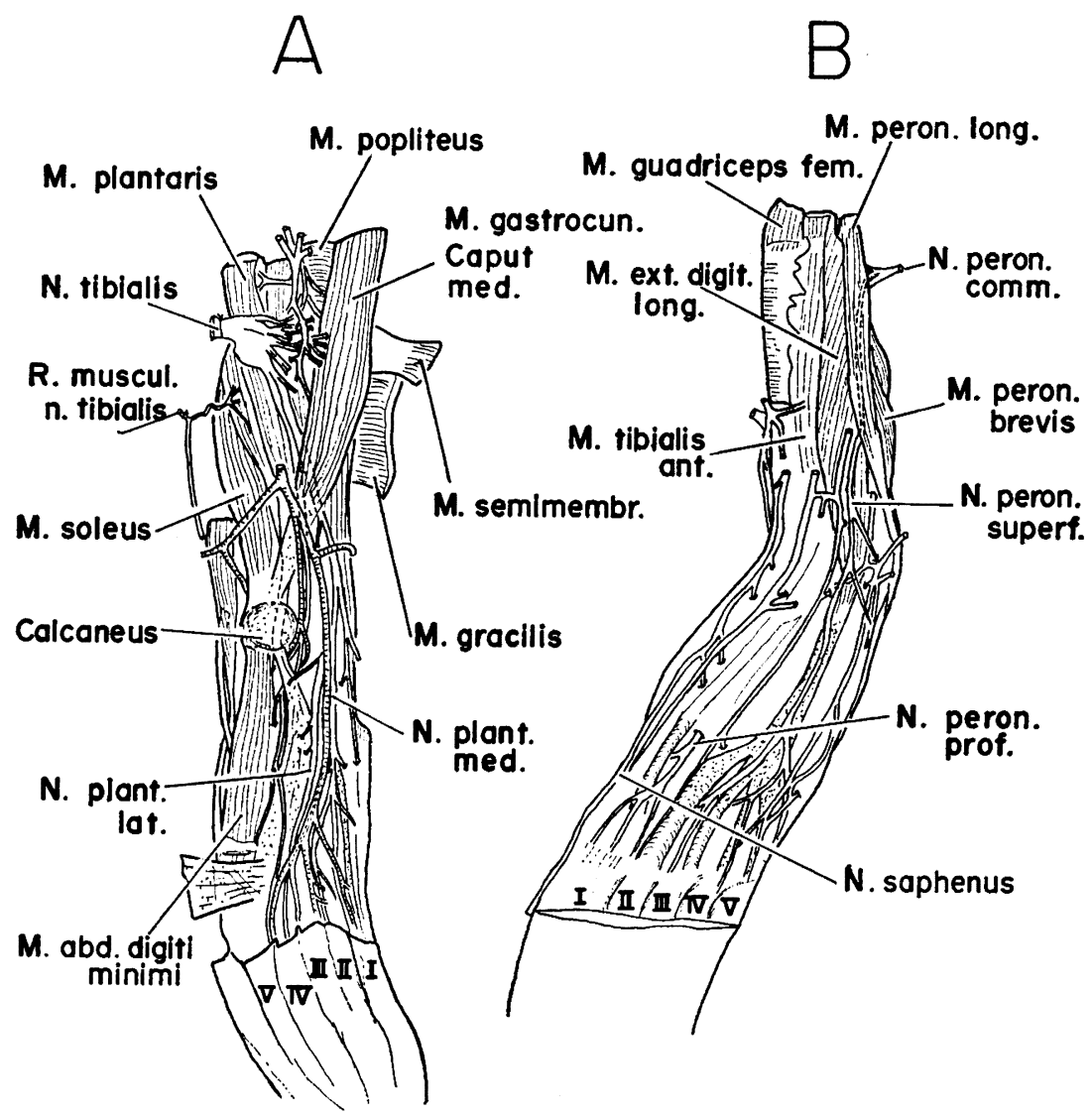

Fig. 7. Left ankle and heel of a male fur seal, in posterior view (A) and anterior view (B). 
sides of the second, third, fourth and fifth toes. The deep peroneal nerve pierces the origins of the peroneus longus and extensor digitorum longus giving off a few branches to the tibialis anterior and extensor hallucis longus. It then pierces the extensor digitorum longus and runs forwards along the dorsum of the foot to be distributed to the skin of the adjacent sides of the first and second toes.

a) The sural nerve (Figs. 4, 8 and 9)

This nerve arises from the muscular branch of the tibial nerve ventral to the sacroperoneus and enters the cleft between the plantaris and soleus to supply the medial head of the gostrocnemius. At the level of the heel, it is joined by the peroneal communicating branch of the inferior gluteal nerve which arises from the common peroneal nerve. The sural nerve pierces the deep fascia between the sacroperoneus and the tail, and descends on the lateral surface of the tail to end by supplying the skin of the dorsolateral side of the foot.

b) The nerve to the sacroperoneus (Figs. 8 and 9)

This nerve leaves the medial side of the peroneal cmmunicating branch of the inferior gluteal nerve at the level of the caudal border of the tibial nerve. It passes lateral to the caudal muscles where it is posteriorly crossed by the sciatic artery, sends at first a fine filament to the gluteus superficialis and ends by supplying the ventral surface of the sacroperoneus.

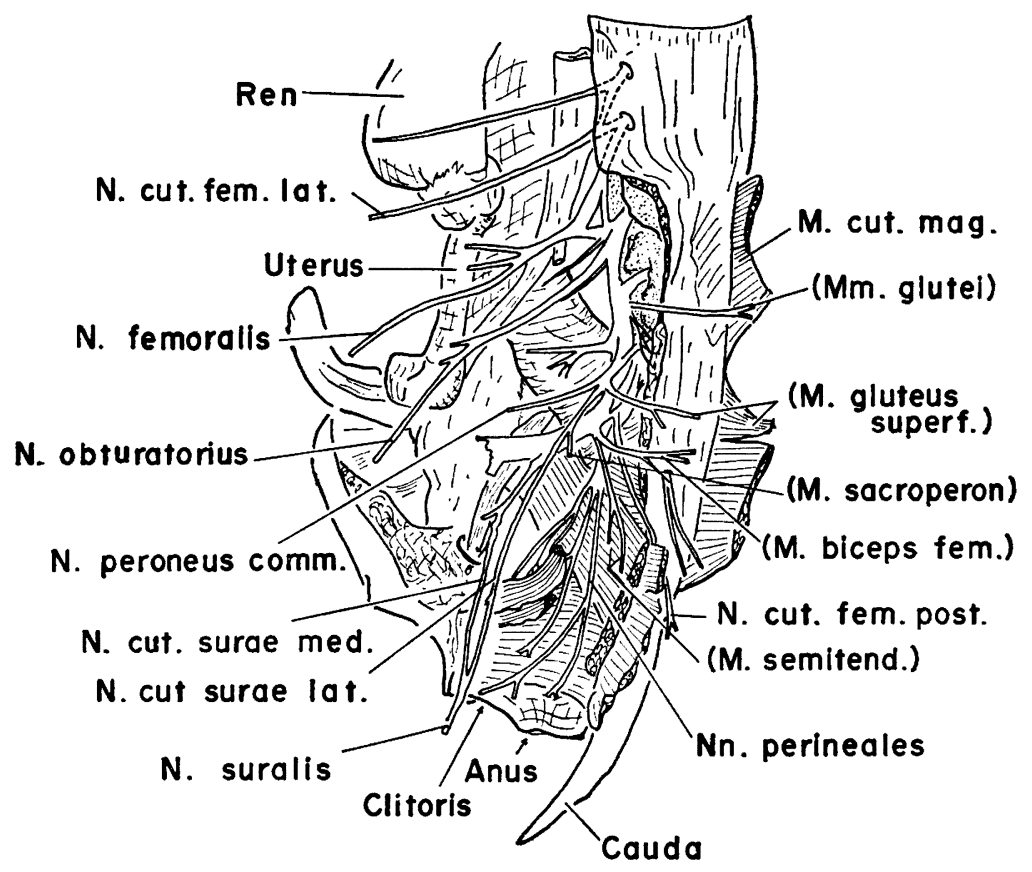

Fig. 8. Ventrolateral view of the pelvic viscera, lumbosacral plexus and its branches in a female fur seal (left side). The hip bone has been removed. 
10) The tibial nerve (Figs. 3, 7, 8 and 9)

This nerve runs transversely along the common peroneal nerve, passes deep to the plantaris and gives off five muscular branches as shown in Figure 7 to the popliteus, gastrocnemius, tibialis posterior, flexor hallucis longus, flexor digitorum longus and plantaris. Its main trunk divides into a lateral and a medial plantar nerve lateral to the plantaris. Both these nerves descend together with the posterior tibial and peroneal arteries and pass medial to the heel to the sole of the foot, where the lateral plantar nerve supplies the skin of the adjacent sides of the fourth and fifth toes. The medial one supplies the skin of all the toes excepting the little toe.

11) The nerve to the levator ani (Fig. 9)

This nerve arises from $\mathrm{Co}_{1}$ to enter the cranial margin of the levator ani.

12) The pudendal nerve (Figs. 8 and 9)

a) The inferior rectal nerves

These consist of the cutaneous branches of the perineal nerve and the muscular branches of the dorsal nerve of the penis or clitoris. The cutaneous branches pierce the caudal part of the biceps femoris and run on the dorsal surface of this muscle to supply the skin around the anus. On the other hand, the muscular branches are distributed to the ischiocavernosus, bulbospongiosus and spincter ani externus.

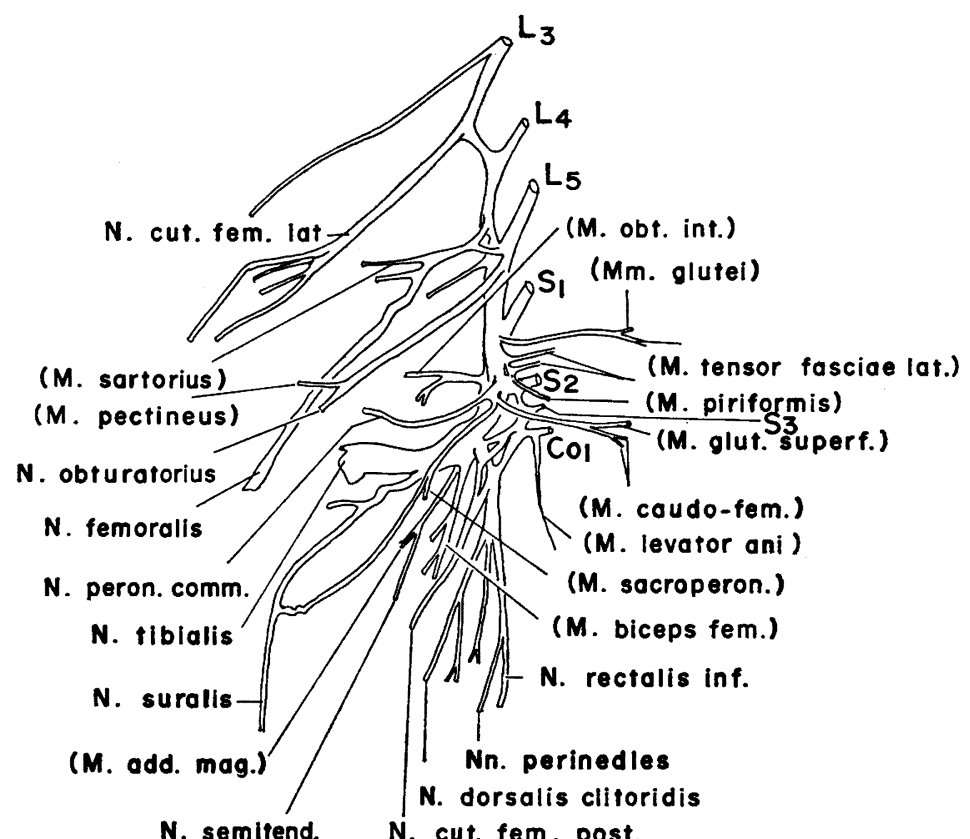

Fig. 9. Lumbosacral plexus of a fur seal. 


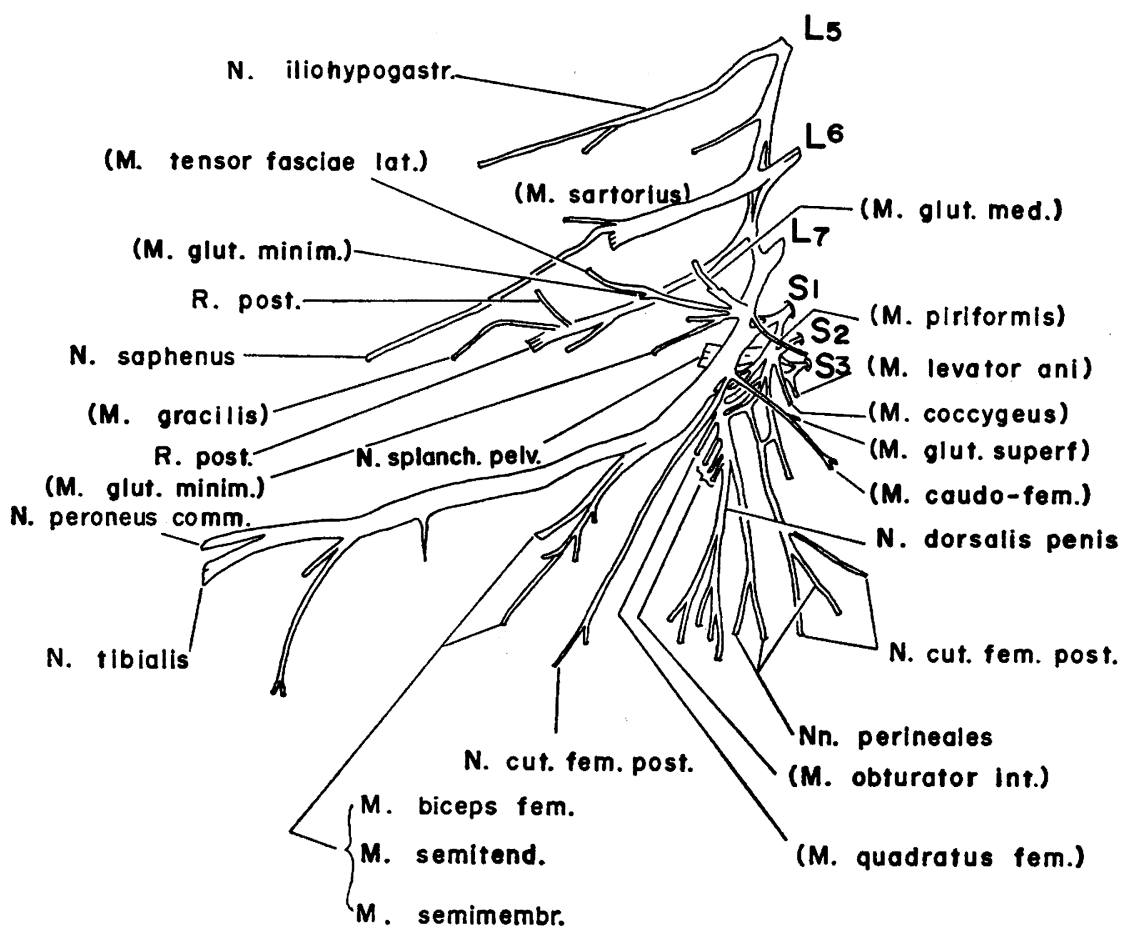

Fig. 10. Lumbosacral plexus of a cat.

b) The perineal nerve

This nerve forms the originating common trunk with the dorsal nerve of the penis or clitoris. It descends on the lateral surfaec of the levator ani accompanying the sciatic artery, and pierces the ventral portion of the semitendinosus, where it divides into three branches to supply the skin around the vulva and over the testis.

c) The dorsal nerve of the penis or clitoris

This nerve passes with the internal pudendal artery ventral to the perineal nerves. It lies close to the medial surface of the ischium, lateral to the levator ani, and enters the medial border of the ischiocarvernosus to reach the penis or clitoris.

13) The pelvic splanchnic nerves

These arise as one or two slender filaments from the loop between $\mathrm{S}_{2}$ and $\mathrm{S}_{3}$ or between $\mathrm{S}_{3}$ and $\mathrm{Co}_{1}$, and form the inferior hypogastric plexus with the hypogastric nerve lateral to the rectum.

\section{Discussion}

The northern fur seal is one of the eared seals. Being an aquatic carnivore, it displays numerous adaptation for life and locomotion in 
water. Its paddle-like limb is one. Much of its femur and crus is included within the body wall and only the foot is webbed. It is thus very important to discuss the difference in musculature and nerve supply in the posterior limbs of the fur seal and a representative species of terrestrial carnivore such as the cat.

1. Comparison of the bones of the fur seal and cat

As mentioned above, the vertebral column of the fur seal is different from that of the cat in its number of regional vertebrae. However, the total number of presacral vertebrae is the same in both species, even though the fur seal has fifteen pairs of ribs. These findings are suggestive of an atavistic phenomenon in the fur seal and offer favorable argument for the theory of phylogenetic shortening of the vertebral column. The femur and crus, as shown in Table 2, are relatively larger in the kitten than the fur seal, while the foot is considerably larger in the fur seal than the kitten. This appears to be related to the different modes of locomotion in and out of water; namely, the femur and crus of the fur seal are embedded within the body wall and can not be moved efficiently in water.

2. Comparison of the muscles of the fur seal and cat

Several reports in the literature have described the morphology of the muscles of eared seals (Murie, ${ }^{1213)} 1872$, 1874-Otarir jubata; Howell ${ }^{7}$, 1928-Zalophus calfornians ; Mori, ${ }^{11}{ }^{1958-Z a l o p h u s ~ j a p a n i c u s) . ~ I n ~ g e n e r a l, ~}$ our observations reveal conditions which correspond well with the data given by the above authors. Details of certain muscles to be discussed specifically here are given in Table 3.

Klaatsch $\left.(1902)^{8}\right)$ suggested that the accessory head of the flexor cruris lateralis (long head of the biceps femoris) of lower mammals becomes the caudofemoralis of higher species. The work of Howell $(1928)^{7)}$ indicated that no discrimination could be made between the biceps femoris, caudofemoralis and gluteus superficialis. According to our observations, the caudofemoralis is represented in man by a part of the gluteus maximus (superficialis) since both muscles are innervated by the inferior gluteal nerve. It is logical to believe therefore that the three muscles, gluteus superficialis, caudofemoralis and caput longum m. bicipitis femoris, represent a closely related formation: These three muscles in the fur seal form a fine muscular plate which arises from the spines of $\mathrm{Co}_{\mathrm{I}}$ to $\mathrm{Co}_{\mathrm{VII}}$ and is inserted into the upper part of the fibula. Based on these observations, it would appear that these muscles in the fur seal have remained in a primitive condition.

On the other hand, - Mori (1958) reported that the sacroperoneus is band-like and overlain by the biceps femoris, arising with two heads which fuse and are: inserted into. the fascia of the shank. We also found the muscle corresponding to the sacroperoneus described and named by Mori (1958) $)^{11}$ in the fur seal. It is innervated by a branch 
of the common peroneal nerve. According to Crouch (1969) ${ }^{4}$, the tenuissimus or abductor cruris caudalis of the cat originates on the transverse process of $\mathrm{Co}_{\mathrm{II}}$, is inserted with the biceps femoris and supplied by the peroneal portion of the sciatic nerve. Klaatsch $(1902)^{8)}$ observed the short head of the biceps femoris in various vertebrates and concluded that this head is the homolog of the tenuissimus which remains in a relatively primitive condition. Therefore, it is reasonable to suppose that the sacroperoneus described by Mori $(1958)^{11)}$ corresponds to the tenuissimus of the cat and the short head of the biceps femoris of man.

3. Comparison of the nerves of the fur seal and cat

Our observations indicate three differences in the patterns of arrangement of the lumbosacral plexus and its branches in the two species. 1. The nerves entering into the composition of the lumbosacral plexus in the fur seal are situated one segment more caudally than in the cat (Figs. 9 and 10). 2. The common peroneal nerve of the fur seal arises in common with the inferior gluteal nerve and sural communicating branches from the dorsal surface of the lumbosacral plexus (Figs. 8 and 9). 3. There are two nerves to the hamstring muscles in the fur seal, one of which enters the long head of the biceps femoris and the other enters the semitendinosus, semimembranosus and adductor magnus, whereas the nerves in the cat arise with at common trunk at the origin from the sciatic nerve (Fig. 10).

Studies on the relationship between variations in the lumbosacral plexus and number of vertebrae have greatly advanced on the basis of the work of Bardeen \& Elting (1901) ${ }^{1)}$, Ssoson-Jaroschewitsch $(1962)^{16)}$, Frede $(1935)^{6)}$, Matwejew (1937) $)^{9)}$ and Horwitz (1939) ${ }^{6}$. They demonstrated that transmutation of a vertebra fowards and backwards is frequently accompanied by a corresponding shift in the spinal nerves. Primary differences should first be discussed. In the present case, as mentioned above, the total number of presacral vertebrae is the same in the fur seal and cat even though the numbers of regional vertebrae are different, whereas the spinal nerve contributing to the lumbosacral plexus are shifted caudally by one segment in the fur seal compared to the cat. These results demonstrate that the innervation of the posterior limb muscles can take place independently of the sclerotomes.

Regarding secondary and tertiary differences, it is interesting to consider the manner in which the arrangement of the common peroneal nerve in the plexus is related to the modes of attachment and size of the limb muscles supplied by it. As mentioned above, the distal displacement of the hamstring muscles is more remarkable in the fur seal than the cat, while the nerves to these muscles number two in the fur seal against one in the cat. The muscles supplied by the common peroneal nerve are relatively larger in the fur seal than in the kitten as 
indicated in Table 5, whereas this nerve divides proximately from the lumbosacral plexus. Comparative anatomical studies by Miller (1934) ${ }^{103}$ have shown that the arrangement of the peripheral portion of the plexus is determined by the size and position of the muscles which are supplied by it. This agrees well with our findings, and it may be taken as a general rule that the distal displacement and size-increase of a muscle are accompanied by a high division in the plexus of the nerve supplying it.

Finally, the weights of the posterior limb muscles will be discussed. Bauschulte (1972) ${ }^{2}$ analysed the posterior limb muscles of monkeys and kangaroos morphologically and biomechanically. Bryden \& Felts (1974) observed four species of Antarctic seals and compared the sizes of their bones, muscle groups and individual muscles. Schumacher et al. $(1962)^{15)}$ studied statistically the relationships between the dry and wet muscle weights and demonstrated a logarithmic transformation in both cases. They compared the relative weights of the dry or wet muscles of the fur seal fetus and kitten, and also made a comparison with data derived from Bauschulte $(1972)^{2)}$ and Bryden \& Felts (1974) ${ }^{3)}$. As indicated in Table 5, the muscles examined in this study were divided into eight groups on the basis of their innervation. The muscles innervated by the femoral nerve are relatively larger in the kitten than the fur seal. The muscles supplied by the inferior gluteal and common peroneal nerves are considerably larger in the fur seal than the kitten. Against this, the muscles supplied by the ventral portion of the lumbosacral plexus are almost the same in the two species. These observations may therefore be interpreted as suggesting that the arrangement of the lumbosacral plexus tends to be conservative throughout different ver-

Table 5. The percentage of the dry weight of muscle groups supplied by the different nerves to the total weight of the posterior limb muscles

\begin{tabular}{|c|c|c|c|}
\hline & Muscles supplied by & Kitten & $\begin{array}{l}\text { Fetal } \\
\text { fur seal }\end{array}$ \\
\hline \multirow{6}{*}{ 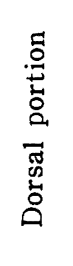 } & femoral $\mathrm{n}$ & 26.2 & 15.2 \\
\hline & superior gluteal $\mathrm{n}$. & 7.5 & 9.8 \\
\hline & inferior gluteal $\mathrm{n}$. & 1.5 & 4.1 \\
\hline & common peroneal $\mathrm{n}$. & 6.4 & 15.4 \\
\hline & sacral plexus & 0.6 & 0.5 \\
\hline & total & 42.2 & 45.0 \\
\hline \multirow{4}{*}{ 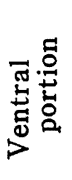 } & obturator $\mathrm{n}$. & 13.9 & 11.3 \\
\hline & tibial n. & 41.3 & 41.1 \\
\hline & sacral plexus & 2.9 & 2.6 \\
\hline & total & 58.0 & 55.0 \\
\hline
\end{tabular}


tebrates, whereas the size of the muscles which are supplied by this plexus vary according to the actual life environments.

Bauschulte (1972) $)^{2)}$ stated that " die prozentualen Anteile der Trockengewichte der Funktionsgruppen als $\mathrm{Ma} \beta$ für die Muskelarbeit verglichen werden". We compared after him the weight of the functional muscle groups as a percentage of the total weight of the posterior limb muscles. As indicated in Table 6. a general similarity exists in kangaroos, monkeys and kittens, but some special variations in relative weight occur in the fur seal. That is to say, the muscles acting on the ancle joint and toes are relatively larger in the fur seal than in the other species. Against this, the muscles of the hip and knee joints are well developed in monkeys, kangaroos and kittens, but relatively poorly developed in the fur seal. In particular, the extensors and flexors of

Table 6. The percentage of the dry weight of functional muscle groups to the total weight of posterior limb muscles

\begin{tabular}{|c|c|c|c|c|}
\hline \multirow{2}{*}{$7_{\text {Muscles }}^{\text {Authors }}$} & \multicolumn{2}{|c|}{ Bauschulte } & \multicolumn{2}{|c|}{ Nakanishi \& Yamamotc } \\
\hline & $\begin{array}{c}\text { Monkey } \\
(\%)\end{array}$ & $\underset{(\%)}{\text { Kangaroo }}$ & $\begin{array}{c}\text { Kitten } \\
(\%)\end{array}$ & $\begin{array}{c}\text { Fur seal } \\
(\%)\end{array}$ \\
\hline $\begin{array}{l}\text { Extensors of hip joint; } \\
\text { Glut. sup., Glut. min., Glut. med., } \\
\text { Pir., Isch. lat., Biceps femor. } \\
\text { (Caput long.), Semitend., Semim., } \\
\text { Add. mag., Quadr. fem., Grac. }\end{array}$ & 49.2 & 53.0 & 42.1 & 33.1 \\
\hline $\begin{array}{l}\text { Flexors of hip joint; } \\
\text { Glut. sup., Sart., Rect. fem., } \\
\text { Iliopsoas }\end{array}$ & 16.3 & 13.0 & 13.0 & 7.4 \\
\hline Muscles acting on the hip joint & 65.5 & 66.0 & 55.1 & 40.5 \\
\hline $\begin{array}{l}\text { Extensors of knee joint; } \\
\text { Vast. lat., med., int., Rect. fem., } \\
\text { Sart., Femorococc. (K) }\end{array}$ & 16.5 & 31.4 & 15.6 & 6.0 \\
\hline $\begin{array}{l}\text { Flexors of knee joint; } \\
\text { Ischiocr. lat., Semitend., Semim., } \\
\text { Grac., Popl., Sart. (M), Gastro., } \\
\text { Sol., Plant. }\end{array}$ & 29.0 & 29.5 & 40.4 & 33.8 \\
\hline Muscles acting on the knee joint & 45.5 & 60.9 & 56.0 & 39.8 \\
\hline $\begin{array}{l}\text { Dorsal flexor; } \\
\text { Tib. ant., Ext. digit. long., Ext. } \\
\text { hall. long. }\end{array}$ & 4.7 & 4.8 & 4.3 & 8.6 \\
\hline $\begin{array}{l}\text { Plantar flexors; } \\
\text { Gastrocn., Sol., Plant., Tib. post., } \\
\text { Flex. digit. tib., Flex. digit. fib. }\end{array}$ & 12.1 & 13.1 & 14.6 & 21.2 \\
\hline Muscles acting on the ancle joint & 16.8 & 17.9 & 18. 9 & 29.8 \\
\hline $\begin{array}{l}\text { Flexors of toes; } \\
\text { Flex. digit. tib., Flex. digit. fib., } \\
\text { plant. }\end{array}$ & 3.5 & 7.4 & 3.1 & 8.0 \\
\hline $\begin{array}{l}\text { Extensors of toes; } \\
\text { Ext. digit. long., Ext. digit. brev., } \\
\text { Ext. hall. long., Peron. digit. IV } \\
\text { (K) }\end{array}$ & 1.6 & 1.4 & 2.2 & 5.2 \\
\hline Muscles acting on the toes & 5.1 & 8.8 & 5.3 & 13.2 \\
\hline
\end{tabular}


the hip joint are poor in the seal. These findings appear to be related to the special conditions in the fur seal; namely, the femur and crus of the seal are included within the body wall and only its pes belongs to the free posterior extremity. For comaprative purpose, the data of Bryden \& Felts (1974) $)^{3)}$ are included in Table 7. The relative weight of the posterior limb muscles are generally similar in fur seal and Antarctic seals. However, the weight of the psoas group, gracilis and semitendinosus are relatively smaller in the fur seal. The quadriceps femoris, adductor group and biceps femoris in the fur seal weigh three to four times as much as in the Antarctic seals. Bryden \& Felts $(1974)^{8}$ indicated that the muscles surrounding the spinal column were very large in crabeater seals, while those on elephant seals were relatively small. This may be related mostly to the sinuous movements in water employed by crabeater seals, compared to the undulatory

Table 7. Comparison of the dry muscle weights of the posterior limb in the fur seal and phosid seals.

\begin{tabular}{|c|c|c|c|c|c|c|}
\hline \multirow{3}{*}{ Muscles } & \multirow{2}{*}{\multicolumn{2}{|c|}{$\begin{array}{r}\begin{array}{r}\text { Nakanishi \& } \\
\text { Yamamoto }\end{array} \\
\text { C. ursinus }\end{array}$}} & \multicolumn{4}{|c|}{ Bryden \& Felts } \\
\hline & & & \multirow{2}{*}{$\frac{0 . \operatorname{rossi}}{\%}$} & \multirow{2}{*}{\begin{tabular}{|c|} 
H. lep- \\
tonyx \\
$\%$ \\
\end{tabular}} & \multirow{2}{*}{$\begin{array}{c}\text { L. car- } \\
\text { cinop } \\
\%\end{array}$} & \multirow{2}{*}{$\begin{array}{c}\text { M. leo } \\
\text { nina } \\
\%\end{array}$} \\
\hline & $\mathrm{Wt}(\mathrm{g})$ & $\%$ & & & & \\
\hline $\begin{array}{l}\text { Psoas group; } \\
\text { Iliopsoas, Psoas minor }\end{array}$ & 0.466 & 6.4 & 29.3 & 22.8 & 36.8 & 30.0 \\
\hline $\begin{array}{l}\text { Gluteus group; } \\
\text { Glut. sup., Glut. med., Glut. } \\
\text { mini., Caudofem. }\end{array}$ & 0.913 & 10.6 & 9.0 & 10.0 & 6.3 & 3.9 \\
\hline Tensor fasciae latae & 0.280 & 3.2 & 2.0 & 2.7 & 1.7 & 2.6 \\
\hline $\begin{array}{l}\text { Obturator group; } \\
\text { Obtur. int., Obtur. ext. }\end{array}$ & 0.224 & 2.6 & 1.0 & 2.8 & 1.6 & 2.2 \\
\hline Gemelli sup. et inf. & 0.078 & 0.9 & 0.7 & 1.4 & 0.8 & 1.3 \\
\hline Sartorius & 0.102 & 1.2 & 0.3 & 0.3 & 0.2 & 2.2 \\
\hline Quadriceps femoris & 0.692 & 8.0 & 3.3 & 3.8 & 3.3 & 1.9 \\
\hline Pectineus & 0.053 & 0.7 & 0.6 & 1.1 & 1.0 & 0.4 \\
\hline Gracilis & 0.292 & 3.4 & 8.9 & 10.7 & 9.3 & 16.5 \\
\hline $\begin{array}{l}\text { Adductor group; } \\
\text { Add. mag., Add. brev., Add. } \\
\text { long. }\end{array}$ & 0.508 & 5.9 & 1.5 & 1.3 & 0.7 & 1.3 \\
\hline Biceps femoris & 0.590 & 6.8 & 1.4 & 2.0 & 1.7 & 2.2 \\
\hline Semitendinosus & 0.264 & 3.1 & 8.5 & 8.6 & 6.6 & 7.6 \\
\hline Semimembranosus & 0.193 & 2.2 & 4.0 & 1.3 & 1.0 & 1.6 \\
\hline $\begin{array}{l}\text { Extensors in crus; } \\
\text { Tibial. ant., Ext. hall. long., } \\
\text { Ext. digit. long. }\end{array}$ & 0.738 & 8.6 & 6.7 & 8.7 & 9.0 & 9.1 \\
\hline $\begin{array}{l}\text { Flexors in crus ; } \\
\text { Triceps sur., Plant., Poplit., } \\
\text { Flex. digit. long., Flex. hall. } \\
\text { long., Tibial. post. }\end{array}$ & 2.046 & 23.6 & 22.7 & 22.4 & 19.8 & 17.3 \\
\hline
\end{tabular}


movements of elephant seals. In the fur seal, the muscles surrounding the spinal column are very small. This is consistent with the general life mode of fur seals, which rarely land on islands except during the breeding season and do not need any developed from of terrestrial locomotion. Hence, the semitendinosus, gracilis, and psoas groups used for such movement are poorly developed, but the quadriceps femoris, adductor group and flexors in the crus, which are employed for swimming, are well developed in the fur seal.

\section{Summary}

Comparative anatomical studies of the innervation and musculature of the posterior limb were made on four northern fur seal fetuses, four adult cats and two kittens. The results may be summarized as follows:

1. The numbers of regional vertebrae in the fur seal and cat are different, but the total number of presacral vertebrae in both species is the same.

2. The femur and crus are relatively larger in the kitten than the fur seal, whereas the foot is considerably larger in the fur seal than the kitten.

3. On the basis of their innervation, the gluteus superficialis (maximus), caudofemoralis and caput longum $\mathrm{m}$. bicipitis femoris appear to represent a closely related formation.

4. The sacroperoneus in the fur seal appears to be represented by the tenuissimus in the cat and by the short head of the biceps femoris in man.

5. Based on our observations of the nerve branching patterns and of dry muscle weights, it may be taken as a general rule that the distal displacement and size-increase of a muscle are accompanied by a high division in the plexus of the nerve supplying it.

6. The arrangement of the lumbosacral plexus tends to be conservative throughout different vertebrates, but the relative dry weights of muscles which are applied by this plexus vary from animal to animal according to their life environments.

\section{References}

1) Bardeen, C. R. and Elting, A. W.: A statistical study of the variations in the formation and position of the lumbo-sacral plexus in man. Anat. Anz., 19 : 124-135, 1901.

2) Bauschulte, C.: Morphologische und biomechanische Grundlagen einer functionellen Analyse der Muskeln der Hinterextremität (Untersuchung an quadrupeden Affen und Känguruhs). Z. Anat. Entwickl-Gesch., 138: 167-214, 1972.

3) Bryden, M. M. and Felts, W. J.L.: Quantitative anatomical observations on the 
skeletal and muscular systems of four species of Antarctic seals. J. Anat., 118 : 589-600, 1974.

4) Crouch, J.E.: Text-Atlas of Cat Anatomy. 1st ed., pp. 243-258, Lea \& Febiger, Philadelphia, 1969.

5) Frede, M.: Untersuchungen an der Wirbelsäule und den Extremitäten-plexus der Ratte. Z. Morph. Anthr., 33 : 96-149. 1935.

6) Horwitz, M.T.: The anatomy of (A) the lumbosacral nerve plexus -its relation to variations of vertebral segmentation, and (B), the posterior sacral nerve plexus. Anat. Rec., 74 : 91-107, 1939.

7) Howell, A.B.: Contribution to the comparative anatomy of the eared and earless seals (genera Zalophus and Phoca).

Proceedings of the United States National Museum, 73:1-142, 1928.

8) Klaatsch, H.: Der kurze Kopf des M. biceps femoris und der M. tenuissimus. Ein stammesgeschichtliches Problem. Morph. Jb., 29 : 217-281, 1902.

9) Matwejew, W.P.: Zur Typenanatomie des plexus lumbosacralis. Anat. Anz., 83 : 422-426, 1937.

10) Miller, R. A.: Comparative studies upon the morphology and distribution of the brachial plexus. Am. J. Anat., 54 : 143-175, 1934.

11) Mori, M.: The skeleton and musculature of Zalophus. Okajimas Folia Anat. Jap., 31 : 203-284, 1958.

12) Murie, J.: Researches upon the anatomy of the Pinnipedia. Part 2, Descriptive anatomy of the sea lion (Otaria jubata). Transactions of the Zoological Society of London, $7: 527-596,1872$.

13) Murie, J.: Researches upon the anatomy of the Pinnipedia. Part 3, Descriptive anatomy of the sea lion (Otaria jabata). ibid., $8: 501-582,1874$.

14) Nakanishi, T., Kanno, Y., Takasaki, S. and Kaneshige, T. : Studies on the pudendal nerve. Part 4. A macroscopical observation of the branches of the pudendal plexus in dogs and cats. Hokkaido. J. Med. Sci., 50 : 415-430, 1975.

15) Schumacher, G. H. and Trommer, R. : Die gegenseitige Abhängigkeit des Feuchtund Trockengewichtes und die Bedeutung des Trockengewichtes für die Bestimmung der Arbeit von Skelettmuskeln. Anat. Anz., 111 : 175-188, 1962.

16) Ssoson-Jaroschewitsch, A. J. : Zur Frage über die Zusammensetzung und den Bau des Plexus sacralis. Z. Anat. Entwickl-Gesch., 78 : 626-636, 1926. 